\title{
Research Square \\ Biodegradation of Selected Petroleum Hydrocarbons Using Indigenous Microorganisms
}

Oluwafemi Adebayo Oyewole ( $\Delta$ oa.oyewole@futminna.edu.ng)

Federal University of Technology, Minna Nigeria

Clement S Olusanya

Federal University of Technology, Minna Nigeria

Olusegun I Akinlade

Federal University of Technology Minna Nigeria

Yusuf 0 Abdulwasiu

Federal University of Technology Minna Nigeria

Anthony 0 Kelechi

Federal University of Technology Minna Nigeria

Michael E Okoro

Federal University of Technology Minna Nigeria

\section{Research Article}

Keywords: Biodegradation, Petroleum, indigenous microorganism, Bacteria, Fungi

Posted Date: January 27th, 2022

DOI: https://doi.org/10.21203/rs.3.rs-1267852/v1

License: (c) (i) This work is licensed under a Creative Commons Attribution 4.0 International License.

Read Full License 


\title{
BIODEGRADATION OF SELECTED PETROLEUM HYDROCARBONS USING INDIGENOUS MICROORGANISMS
}

\author{
Oluwafemi A Oyewole, Clement S Olusanya, Olusegun I Akinlade, Yusuf O Abdulwasiu, \\ Anthony O Kelechi and Michael E Okoro \\ Department of Microbiology, Federal University of Technology Minna Nigeria \\ Email Address: oa.oyewole@futminna.edu.ng, Tel: +23481400311875
}

\begin{abstract}
Bioremediation make use of microorganisms to remove contaminants from the environment, the use of indigenous microorganisms in the bioremediation of hydrocarbon pollutant to clean up environment has become a valuable technique. This study was aimed to biodegrade some petroleum hydrocarbon using indigenous microorganism from the petroleum contaminated soil. Top soil sample was collected from petroleum contaminated site in Minna, Nigeria. The petroleum was obtained from a local petrol bunk. The indigenous microorganism with biodegrading potential was obtained by plating the aliquot of the soil sample on minimal salt medium containing petroleum as the only source of carbon. The bacterium was identified by cultural and biochemical test and the fungi were identified by both macroscopic and microscopic examinations. The isolates with optimal potential were then subjected to biodegradation for 25 days. A control was setup without the isolate. Three bacterial isolate and four fungi isolate were isolated from the petroleum contaminated site, the bacterial isolates were Corynebacterium xerosis with maximal rate of degradation on day $20(86 \%)$, the control had 12\%, Proteus vulgaris maximal rate of biodegradation was on day $35(80 \%)$ while that of control is $40 \%$, and Bacillus subtilis maximal rate of biodegradation was on day $10(49.73 \%)$ while that of control is $2.2 \%$. The fungi isolates were identified as Aspergillus niger, A. versicolar, Trichophyton verrucosum Bodin and Saccharomyces cerivisiae. Trichophyton verrucosum Bodin on day 25 had the highest percentage $(88 \%)$ of biodegradation in comparison with the control $41 \%$. While $A$. niger highest biodegradation was observed on day 15 (24\%). There was a gradual increase in the count of all the isolate during the course of biodegradation. The result of this study showed that these isolates were able to degrade petroleum hydrocarbon and can be useful for large scale bioremediation of petroleum contaminated soils.
\end{abstract}

Keywords: Biodegradation, Petroleum, indigenous microorganism, Bacteria, Fungi

\section{INTRODUCTION}

Crude oil and it derivatives is one of the most common contaminants in the environment and due to their wide spread, they pose severe risks to human health and water bodies, hence, intense remediation practices are required at the contaminated sites. Environmental contamination problems from petroleum extraction, transportation and storage are becoming more widely 
recognized around the world. Nigeria's crude oil production has increase to approximately 2.8 million barrel per day. Nigeria is presently Africa tops oil producer and the world sixth largest (Oyewole et al. 2021). The continued usage of petroleum products around the world has resulted in a massive increase in pollution from diesel, spent engine oil, and jet fuel in the environment. As a result, petroleum pollution is one of the most common environmental problems, as it disrupts human metabolism and produces fatal mutations in genetic materials even at low levels of pollution due to their persistence and biological toxicity When crude oil is separated via fractional distillation, diesel fuel is produced; other distillates include aviation fuel, kerosene, and petrol. The amount of carbon in diesel fuel varies between 11 and 25, and the distillation temperature is between 180 and $380{ }^{\circ} \mathrm{C}$. Diesel contains hydrocarbons in the range of 2000 to 4000 , which cannot be separated by gas chromatography. It is made up of 64 percent aliphatic hydrocarbons, 2\% olefinic hydrocarbons, and 35\% aromatic hydrocarbons. It's made up of a variety of hydrocarbons, including n-alkanes, isoalkanes, cycloalkanes, and aromatic hydrocarbons (Ahmed and Fakhruddin 2018). Kerosene is a component of crude oil that is utilized as an energy source. Kerosene is used as a fuel in some jets, as well as an illuminating oil for wicks and lamps. Researchers discovered that kerosene-polluted soil has fewer microorganisms than non-polluted soil. Kerosene toxicity to biota ranges from mild to severe, with product toxicity dependent on the kind and concentration of aromatic compounds. Spills of kerosene have the potential to cause acute poisoning in aquatic life (Hasan 2014).

The term Engine oil can be defined as a thick mineral liquid applied to a machine or engine so as to reduce friction between the moving parts of the machine (Shahida et al. 2015). Mostly in the World today especially in developing countries, lands contaminated with spent engine oil are found due to the ineffective environmental laws which directly affects the rate at which the spent engine oil enters and pollutes the environment. Engine oil was defined as a pollutant or contaminant in the environment that causes damage to the ecosystem as well as health hazard to human beings (Ajiboye et al. 2020). The chemical and physical approach of remediation can create another kind of pollution and are very expensive to implement, while bioremediation make use of microorganism that are environmentally friendly and cost effective compare to physical and chemical treatments. This technology makes use of the capacity of microorganisms to metabolize toxic compounds as source of carbon and energy, it also uses enzymatic and metabolic activities to convert hydrocarbons into less harmful molecules. Bacteria, yeast, and fungi are mostly 
responsible for the cleanup (Farber et al. 2019, Oyewole et al. 2021). Bachmann et al. (2014) refers to biodegradation to be a process that has the ability to change the chemical structure and nature of a pollutant, which is enforced by a biological activity that produces naturally metabolites. Microorganism are used in bioremediation to remove hydrocarbon pollutant from the environment, the indigenous microbial population play significant role in biodegradation, but their performance decline when the pollution concentrations are high, to effectively remove the pollutant, engineered approach such has bio-stimulation and bio-augmentation are used. For the breakdown of aliphatic hydrocarbons, Acinetobacter, Pseudomonas, Rhodococcus, Stenotrophomonas, Alcanivorax, Bacillus and Arthrobacter species have been widely used (Chaudhary et al. 2020), Amorphoteca, Talaromyces, Neosartorya, and Graphium, as well as Candida, were also isolated from petroleumcontaminated soil and found to be potential degraders of hydrocarbons. It was also reported that Aspergillus, Penicillium and Cephalosporium has the ability to degrade hydrocarbon. After being isolated from contaminated water, Candida lipolytica, Rhodotorula mucilaginosa, Geotrichum sp, and Trichosporon mucoides were discovered to degrade petroleum compounds (Das and Chandran 2010). Growth enhancement of the indigenous microorganism, inoculation of foreign oildegrading bacteria and bio-stimulation is one of the approach of accelerating the detoxifying and degrading activities at the oil contaminant site with a very minimal impact on the ecological system (Mukred et al. 2008).

Most organic pollutants are broken down by microorganism under aerobic condition, oxygen is required for the initial intercellular attack of the pollutant and also required for the activation of enzymatic process carried out by oxygenases and peroxidases. Peripheral degradation pathways convert the organic contaminant step by step into intermediates of the central intermediary metabolism, such intermediate include tricarboxylic acid cycle. Cell biomass synthesis occurs from the central precursor metabolites, examples are succinate, pyruvate and acetyl-CoA. Gluconeogenesis produced the sugar necessary for growth and biosynthesis. Enzymatic process by microorganism can be used for the breakdown of petroleum hydrocarbons (Das and Chandran 2011). The amount of oil spilled, the chemical composition of the crude oil or petroleum product, and the biodegrading potential of the microorganism present in the affected area all play a role in the recovery of water and soil after an oil spill. Many environmental elements have an impact on the bioremediation process and should be kept in mind. On the afflicted site, these include $\mathrm{pH}$, 
temperature, pollutant kind and concentration, oxygen, nutrient availability, and microbe

98 concentration (Laurelta et al. 2017).

99 The aim of this study was to isolate, identify and screened microorganism with degrading potential from petroleum contaminated soil.

101

\section{MATERIALS AND METHODS}

\section{Collection of soil sample and petroleum}

104 Top soil samples was collected from petroleum contaminated site in Minna, Nigeria, in a sterilized 105 plastic container and taken to the microbiology laboratory of Federal University of Technology 106 Minna, Nigeria. Petroleum fuel (kerosene, diesel and spent engine oil) used was obtain from local 107 petrol bunk, Minna, Nigeria.

\section{Isolation and Screening of Microorganism}

109 Contaminated soil sample (1g) was collected, serial dilution was performed, and $0.1 \mathrm{ml}$ aliquot of 110 the dilution $10^{-2}$ was dispense into petri-dish and Mineral salt medium + agar agar was poured on 111 it and incubated for 6 days at $30 \pm 2{ }^{\circ} \mathrm{C}$, for bacterial isolation the mineral salt medium consist of $1121.8 \mathrm{~g} \mathrm{~K} \mathrm{HPO}_{4}, 1.2 \mathrm{~g} \mathrm{~K}_{2} \mathrm{HPO}_{4}, 4.0 \mathrm{~g} \mathrm{NH} 4 \mathrm{Cl}, 0.2 \mathrm{~g} \mathrm{MgSO}_{4} .7 \mathrm{H}_{2} \mathrm{O}, 0.1 \mathrm{~g} \mathrm{NaCl}, 0.01 \mathrm{~g} \mathrm{FeSO}$. $7 \mathrm{H}_{2} \mathrm{O}$ in $1131 \mathrm{~L}$ of distilled water, while for fungi, it consists of $1.8 \mathrm{~g} \mathrm{~K}_{2} \mathrm{HPO}_{4}, 1.2 \mathrm{~g} \mathrm{KH}_{2} \mathrm{PO}_{4}, 4.0 \mathrm{~g} \mathrm{NH} 4 \mathrm{Cl}, 0.2 \mathrm{~g}$ $114 \mathrm{MgSO}_{4} .7 \mathrm{H}_{2} \mathrm{O}, 0.01 \mathrm{~g} \mathrm{FeSO}_{4} .7 \mathrm{H}_{2} \mathrm{O}$ in 1Liter of distilled water, petroleum was added as the only 115 energy and carbon source $(1.0 \mathrm{ml}$ per L).

\section{Identification of the Bacterial Isolates}

117 Isolated and screened bacteria were identified by cultural, morphological and biochemical 118 characteristics, following the methods of Cheesbrough (2010).

\section{Identification of the Fungi Isolates}

120 The observed characteristics of the isolates were recorded. Morphological identification was 121 performed for the selected fungal strains. Both macroscopic (cultural characteristics) and 122 microscopic (lactophenol cotton blue staining) examinations were performed on the isolates. The 
123 findings were verified by comparing their morphological and cultural traits to descriptions 124 provided by Tsuneo (2007).

\section{Biodegradation studies with the Bacteria and Fungi isolates}

126 It was done by inoculating $2 \mathrm{ml}$ of 24 hours culture into $18 \mathrm{ml}$ of sterilized minimal salt medium 127 that also contained $2000 \mathrm{mg}$ of petroleum and another control flask was prepared not containing 128 the organism. The conical flasks were incubated at $30^{\circ} \mathrm{C}$ for 25 days, and shaken regularly. At 5 129 day interval, two conical flasks were removed (organism and control).

\section{Determination of Biodegradation activities}

131 The extent of petroleum fuel biodegradation in the mixture was determined by emptying the 132 mixture with diethylether in a separating funnel, after shaking vigorously, the separating funnel 133 was put on the retort stand and allow to separate the organic phase from the liquid phase, the tap 134 was open to remove the MSM while the solvent oil-mixture was collected into a beaker of a known 135 weight. The solvent was evaporated using a water bath. The new weight of the beaker consisting 136 of residual oil was recorded (Dadrasnia and Agamuthu 2013). The rate of degradation of the 137 hydrocarbons were calculated using the formula of Abioye et al. (2013).

$138 \%$ Biodegradation $=\frac{\text { weight of inital oil }- \text { weigth of residual oil }}{\text { weight of inital oil }} \times 100$

\section{RESULTS}

\section{Microorganisms isolated from the petroleum hydrocarbon contaminated soil}

142 The cultural, morphological and biochemical characteristics of the bacterial isolates indicated that 143 the species were: Corynebacterium xerosis was isolated from diesel, Proteus vulgaris, 144 Trichophyton verrucosum Bodin and Saccharomyces cerevisiae were isolated from kerosene while 145 Bacillus subtilis, Aspergillus niger and A. versicolor were isolated from the spent engine oil (Table $1461)$. 


\begin{tabular}{lll}
\hline $\begin{array}{l}\text { Petroleum } \\
\text { hydrocarbon }\end{array}$ & Bacteria & Fungi \\
\hline Diesel & $\begin{array}{l}\text { Corynebacterium } \\
\text { xerosis }\end{array}$ & - \\
Kerosene & Proteus vulgaris & $\begin{array}{l}\text { Trichophyton } \\
\text { verrucosum Bodin }\end{array}$ \\
& & $\begin{array}{l}\text { Saccharomyces } \\
\text { cerevisiae }\end{array}$ \\
& & \\
Spent Engine oil & Bacillus subtilis & Aspergillus niger \\
& & A. versicolor \\
\hline
\end{tabular}

150

151

152

153

154

155

156

157

158

159

160

161

162

163

164

165

\section{Rate of biodegradation}

The diesel biodegradation by Corynebacterium xerosis for 25 days is shown in Table 2. the percentage of diesel degradation by the bacterial on day 20 had the highest percentage (86\%) of biodegradation in comparison with the un-inoculated control $12 \%$, while the total kerosene of kerosene contaminated soil treated by the isolate for 25 days is shown in Table 4 . That of kerosene maximal biodegradation percentage was on day 25 with $80 \%$ while that of control is $40 \%$ by Proteus vulgaris while percentage of kerosene degradation by the Trichophyton verrucosum Bodin on day 25 had the highest percentage (88\%) of biodegradation in comparison with the control $41 \%$. The total spent engine oil degradation on day 10 had the highest rate of degradation with a value of $49.73 \%$ and control 2.2 by Bacillus subtilis and The biodegradation rate of spent engine oil by A. niger had the highest biodegradation on day 15 having percentage degradation of $24 \%$ shown in Table 4 
Table 2 Diesel biodegradation by Corynebacterium xerosis

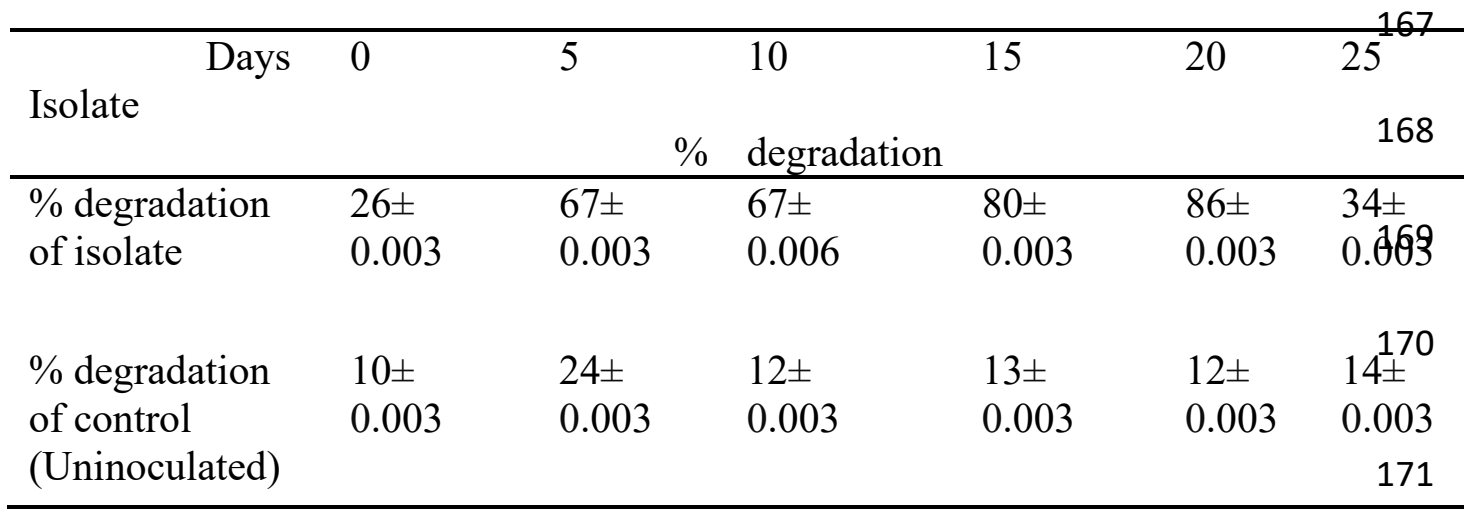

172

173 Table 3 Mean of kerosene biodegradation by the isolate

\begin{tabular}{|c|c|c|c|c|c|c|c|}
\hline $\begin{array}{l}\text { Days } \\
\text { Isolate }\end{array}$ & 0 & 5 & $\begin{array}{l}10 \\
\text { degradation }\end{array}$ & 15 & 20 & 25 & 175 \\
\hline $\begin{array}{l}\text { Proteus } \\
\text { vulgaris }\end{array}$ & $\begin{array}{l}18 \pm \\
0.001^{d}\end{array}$ & $\begin{array}{l}29.0 \pm \\
0.009^{b}\end{array}$ & $\begin{array}{l}36 \pm \\
0.001^{d}\end{array}$ & $\begin{array}{l}37 \pm \\
0.000^{\mathrm{a}}\end{array}$ & $\begin{array}{l}56 \pm \\
0.006^{\mathrm{b}}\end{array}$ & $\begin{array}{l}80 \pm \\
0.001^{\mathrm{c}}\end{array}$ & 176 \\
\hline $\begin{array}{l}\text { Control } \\
\text { (Uninoculated) }\end{array}$ & $\begin{array}{l}10 \pm \\
0.000^{\mathrm{a}}\end{array}$ & $\begin{array}{l}25 \pm \\
0.003^{\mathrm{a}}\end{array}$ & $\begin{array}{l}23 \pm \\
0.003^{b}\end{array}$ & $\begin{array}{l}28 \pm \\
0.000^{\mathrm{b}}\end{array}$ & $\begin{array}{l}32 \pm \\
0.006^{\mathrm{a}}\end{array}$ & $\begin{array}{l}40 \pm \\
0.003^{\mathrm{a}}\end{array}$ & 178 \\
\hline $\begin{array}{l}\text { Trichophyton } \\
\text { verrucosum }\end{array}$ & $\begin{array}{l}12 \pm \\
0.001^{\mathrm{c}}\end{array}$ & $\begin{array}{l}49 \pm \\
0.003^{c}\end{array}$ & $\begin{array}{l}12 \pm \\
0.003^{\mathrm{a}}\end{array}$ & $\begin{array}{l}80 \pm \\
0.000^{\mathrm{b}}\end{array}$ & $\begin{array}{l}81 \pm \\
0.001^{\mathrm{c}}\end{array}$ & $\begin{array}{l}88 \pm \\
0.003^{d}\end{array}$ & 179 \\
\hline $\begin{array}{l}\text { Control } \\
\text { (Uninoculated) }\end{array}$ & $\begin{array}{l}0.05 \pm \\
0.00^{\mathrm{b}}\end{array}$ & $\begin{array}{l}23 \pm \\
0.003^{\mathrm{a}}\end{array}$ & $\begin{array}{l}27 \pm \\
0.005^{\mathrm{c}}\end{array}$ & $\begin{array}{l}27 \pm \\
0.000^{\mathrm{b}}\end{array}$ & $\begin{array}{l}31 \pm \\
0.000^{\mathrm{a}}\end{array}$ & $\begin{array}{l}41 \pm \\
0.003^{b}\end{array}$ & 180 \\
\hline
\end{tabular}




\begin{tabular}{|c|c|c|c|c|c|c|}
\hline $\begin{array}{l}\text { Microbial } \\
\text { Isolate(Days) }\end{array}$ & 0 & 5 & 10 & 15 & 20 & 25 \\
\hline $\begin{array}{l}\text { Bacillus } \\
\text { subtilis }\end{array}$ & $\begin{array}{l}0.00 \pm \\
0.000^{\mathrm{a}}\end{array}$ & $\begin{array}{l}0.00 \pm \\
0.000^{\mathrm{a}}\end{array}$ & $\begin{array}{l}49 \pm \\
0.001^{\mathrm{c}}\end{array}$ & $\begin{array}{l}45 \pm \\
0.001^{b}\end{array}$ & $\begin{array}{l}41 \pm \\
0.000^{c}\end{array}$ & $\begin{array}{l}46 \pm \\
0.000^{c}{ }_{186}\end{array}$ \\
\hline $\begin{array}{l}\text { Control } \\
\text { (Uninoculated) }\end{array}$ & $\begin{array}{l}7.46 \pm \\
0.000^{\mathrm{c}}\end{array}$ & $\begin{array}{l}18.41 \pm \\
0.000^{\mathrm{c}}\end{array}$ & $\begin{array}{l}2.2 \pm \\
0.006^{\mathrm{b}}\end{array}$ & $\begin{array}{l}3.86 \pm \\
0.007^{\mathrm{c}}\end{array}$ & $\begin{array}{l}3.03 \pm \\
0.006^{\mathrm{b}}\end{array}$ & $\begin{array}{l}3.23 \pm \\
0.003^{\mathrm{b}}\end{array}$ \\
\hline $\begin{array}{l}\text { Aspergillus } \\
\text { niger }\end{array}$ & $\begin{array}{l}4 \pm \\
0.000^{\mathrm{b}}\end{array}$ & $\begin{array}{l}7 \pm \\
0.000^{\mathrm{b}}\end{array}$ & $\begin{array}{l}21 \pm \\
0.003^{a}\end{array}$ & $\begin{array}{l}27 \pm \\
0.006^{\mathrm{a}}\end{array}$ & $\begin{array}{l}24 \pm \\
0.003^{\mathrm{a}}\end{array}$ & $\begin{array}{l}18 \pm \quad 188 \\
0.006^{\mathrm{a}}\end{array}$ \\
\hline $\begin{array}{l}\text { Control } \\
\text { (Uninoculated) }\end{array}$ & $\begin{array}{l}0.00 \pm \\
0.000^{\mathrm{a}}\end{array}$ & $\begin{array}{l}2 \pm \\
0.000^{\mathrm{b}}\end{array}$ & $\begin{array}{l}4 \pm \\
0.006^{b}\end{array}$ & $\begin{array}{l}5.5 \pm \\
0.007^{\mathrm{b}}\end{array}$ & $\begin{array}{l}6.5 \pm \\
0.006^{b}\end{array}$ & $\begin{array}{l}7.5 \pm^{189} \\
0.003^{b} 190\end{array}$ \\
\hline
\end{tabular}

193 The growth of the isolate during biodegradation is shown in Table 6, 7, 8. Figure 1 shows that 194 Corynebacterium xerosis on day 0 had a count of $4 \times 10^{6}$ and the highest on day 25 with a count 195 of $270 \times 10^{6} \mathrm{Cfu} \mathrm{g}^{-1}$, Figure 2 shows that Bacillus subtilis had the minimum count of $1.6 \times 10^{4}$ 196 on day 5 and maximal of $3.2 \times 10^{4}$ on day 25 and Aspergillus niger had $1.5 \times 10^{2}$ on day 0 and 6.6 $197 \times 10^{2} \mathrm{~g}^{-1}$ on day 15 . Figure 3 shows Proteus vulgaris having the highest on day 25 with a viable 198 count of $56 \times 10^{5} \mathrm{Cfu} \mathrm{g}^{-1}$, with the minimum on day 5 of $1 \times 10^{5} \mathrm{Cfu} \mathrm{g}^{-1}$ and Trichophyton 199 verrucosum having the highest on day 25 with a viable count of $5 \times 10^{6} \mathrm{Cfu}^{-1}$ with the minimum 200 on day 5 of $1 \times 10^{6} \mathrm{cfu} \mathrm{g}^{-1}$ 


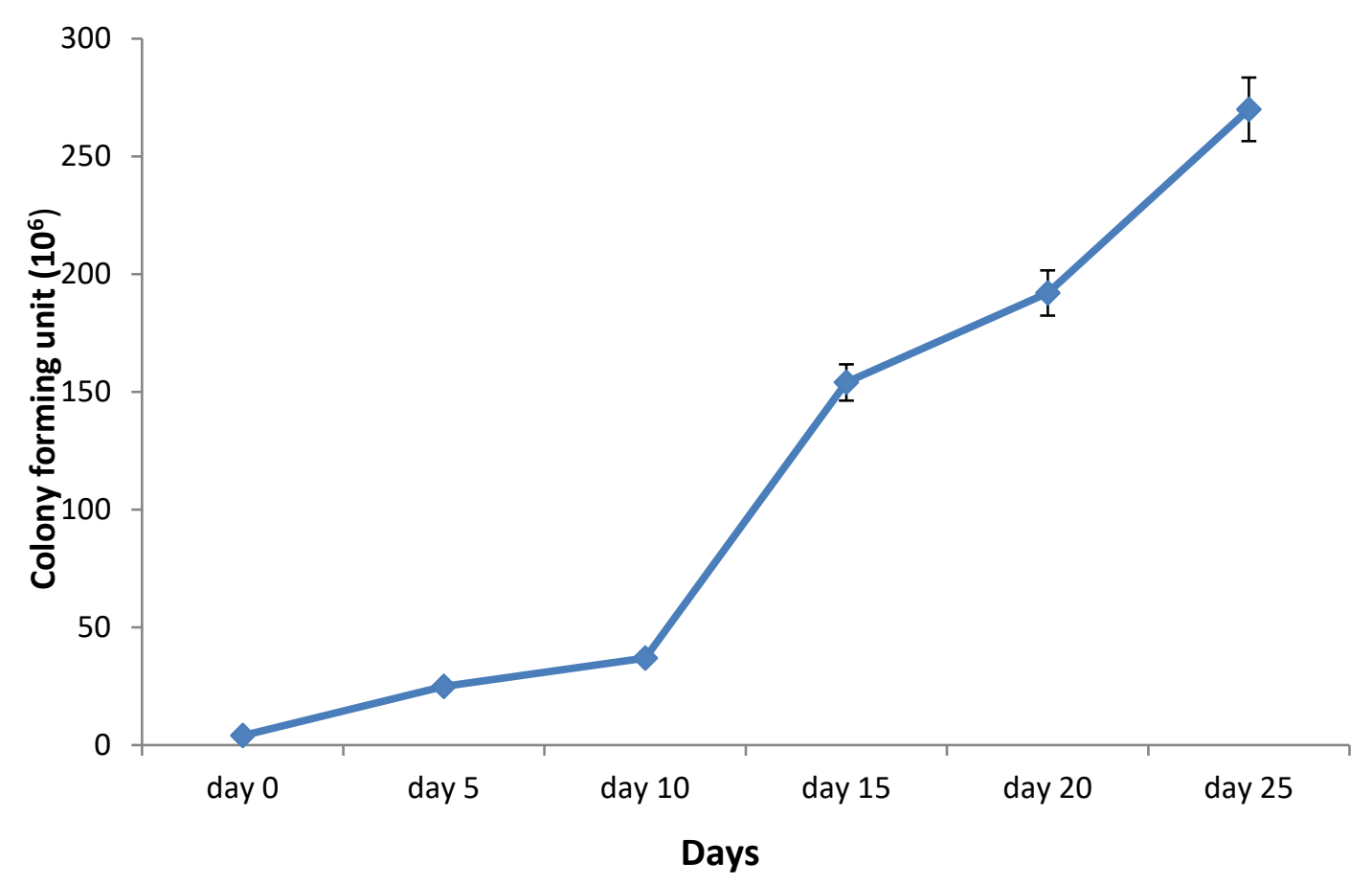

201

202 Figure 3 . Growth profile of the organism at $30{ }^{\circ} \mathrm{C}$ for 25 days during diesel biodegradation 203

204

205

206

207

208 


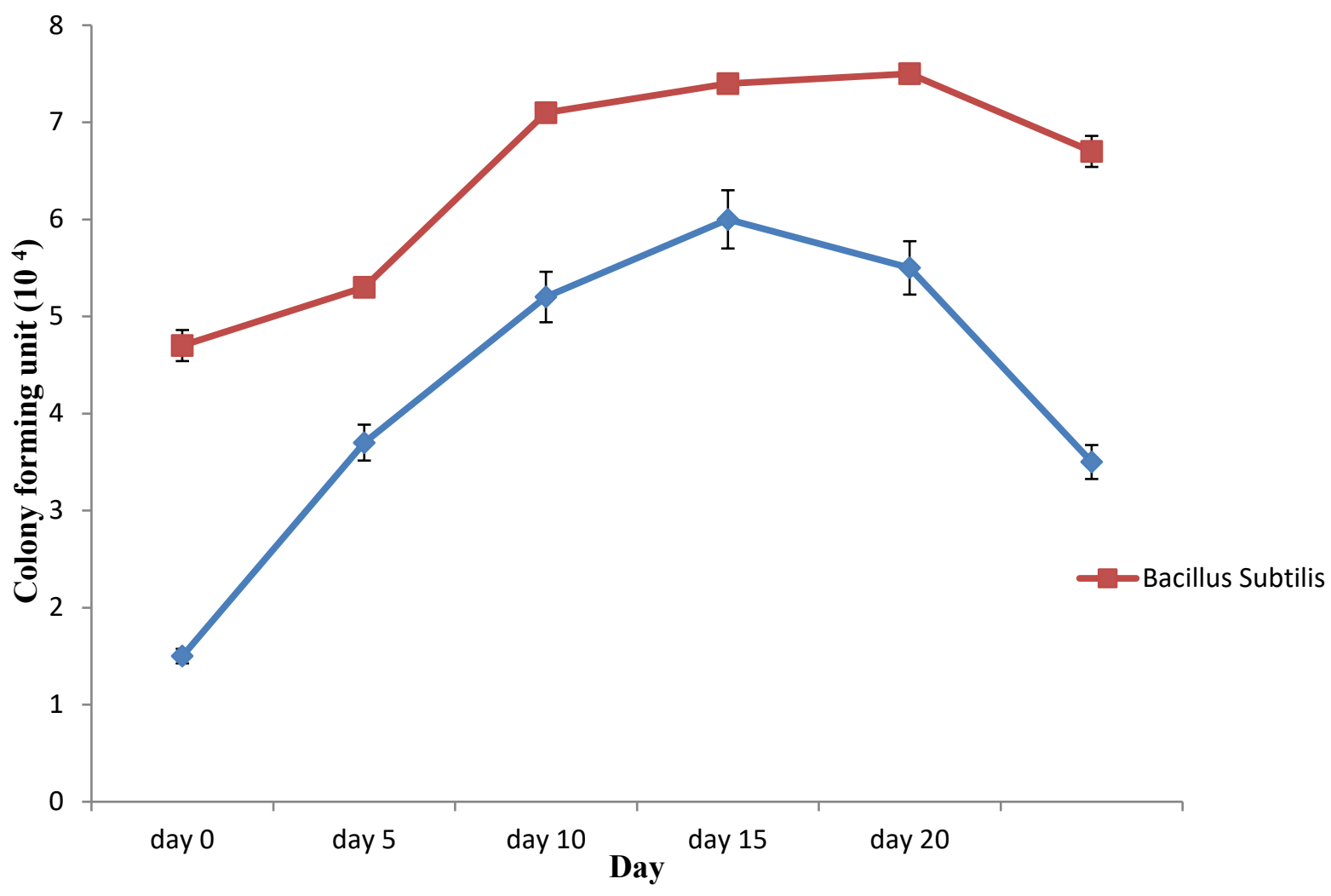

209

210

211 Figure 4. Growth profile of the organism at $30{ }^{\circ} \mathrm{C}$ for 25 days during spent engine oil 212 biodegradation

213

214 


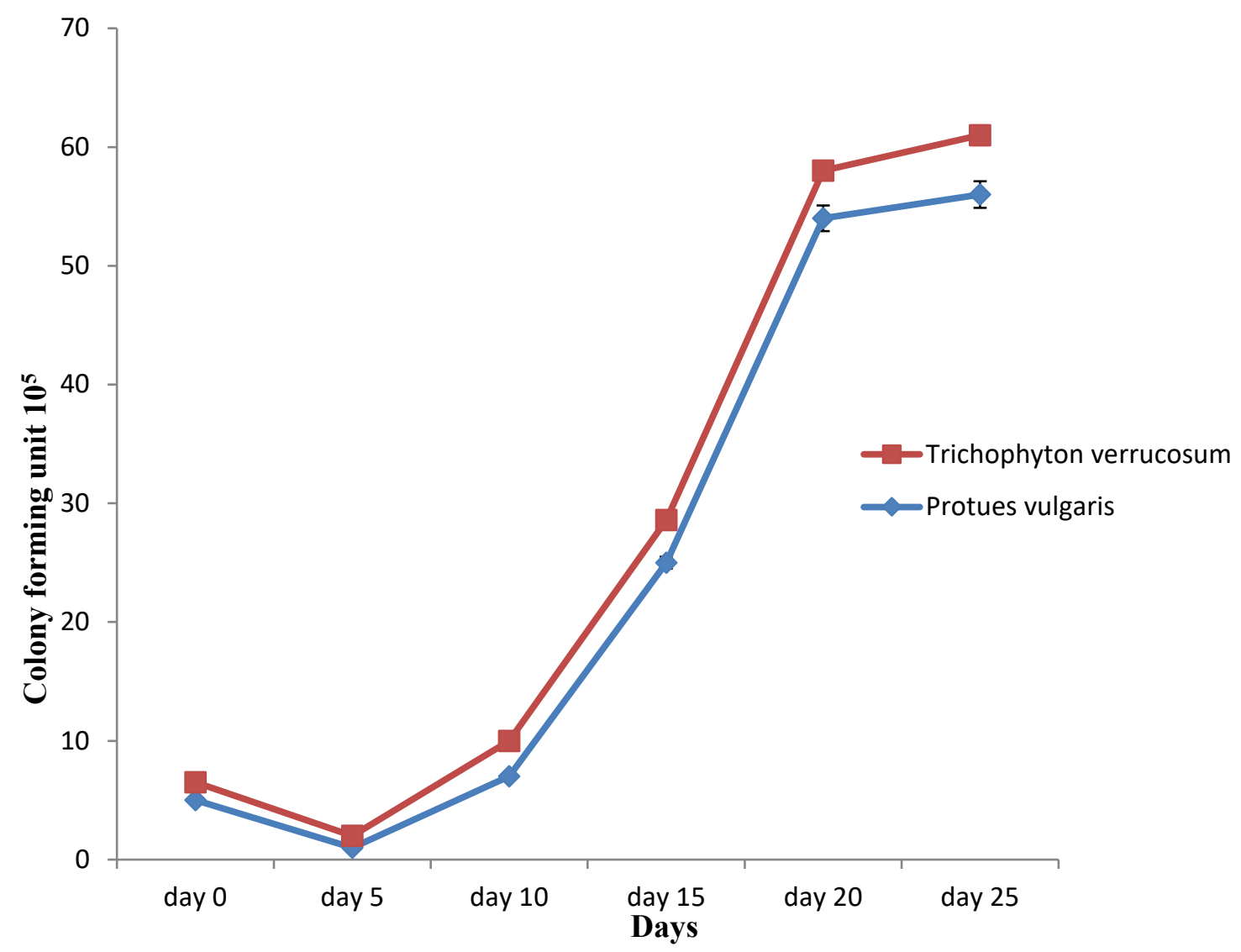

215

216 Figure 5. Growth profile of the organism at $30^{\circ} \mathrm{C}$ for 25 days during kerosene biodegradation

217

218

219

220

221

222

223

224

225 


\section{DISCUSSION}

227 After the screening, a total of 3 bacterial genera and 4 fungi species were isolated from the various

228 petroleum contaminated soil. Petroleum hydrocarbon biodegradation by natural population of microorganisms represents one of the primary mechanisms through which these pollutant can be eliminated from the environment, hydrocarbon-degrading microorganism are many in the environment, even in pristine ones, however, prior exposure to hydrocarbons largely influence their abundance in various environments and communities exposed to hydrocarbon become adapted, the phenomenon of adaption is a consequence of three interrelated mechanism such as induction or depression of specific enzymes that degrade hydrocarbon, selective enrichment of microorganisms able to transform the hydrocarbons and genetic change which result in new metabolic capabilities (Lima et al. 2020).

237 The use of indigenous microorganism facilitate the identification of microorganism with optimal

238 biodegradation potential for petroleum hydrocarbon, the added Petroleum provide nutrient for the species that have the inherent petroleum hydrocarbon utilizing potential, while the less adapted species among the heterotrophic population are gradually eliminated, hence resulting to only one isolate that was chosen based on its ability to grow on Mineral salt agar with $1 \%$ (v/v) of diesel oil at $37^{\circ} \mathrm{C}$ after 5 day, Mukred et al. (2008) also used a similar approach for their isolation and came up with 3 bacterial isolates, Most biodegradation studies have shown that the potential for microbial degradation isolated from petroleum hydrocarbon polluted soil was higher than those isolated from non-polluted sites (Ali 2018). Various petroleum utilizing bacteria and fungi were isolated from the oil contaminated soil, of which most of these as been genera had already been found in oil contaminated soil and identify as petroleum oil degrader. The bacterial isolate used in this study was identified has Corynebacterium xerosis, Proteus vulgaris and Bacillus subtilis, in similar to Ekanem and Ogunjobi (2017) who also isolate Corynebacterium sp, Proteus sp, Bacillus sp, Micrococcus sp, Pseudomonas sp from oil contaminated soil. Corynebacterium genera was the only microorganism from diesel contaminated soil suggesting that it has the ability to resist the toxic effect of diesel oil in similar to Rahman et al. (2002) who also reported Corynebacterium $\mathrm{sp}$ has the dominance bacteria in diesel station soil, the dominance of this genus revealed that it has developed the ability to utilize the oil as a sole carbon and energy sources. 
The genus Bacillus sp is another outstanding bacterial genus reported as petroleum degrader, their ability to form spores when nutrients are limiting makes species of Bacillus self-sustainable bioremediation tools, the strains, Bacillus thurengiensis and Bacillus pumilus were able to on solid media containing naphthalene, phenantherene, anthracene and pyrene as the sole source carbon (Lima et al. 2020). The relatively low number of bacterial count observed in oil contaminated soil can be attributed to the toxic effect of petroleum contamination, and their ability to survive can be due to the presence of hydrocarbon degrading enzyme system and the presence of catabolic genes involved in biodegradation (Ekanem and Ogunjobi 2017).

The fungi isolated from the petroleum contaminated soil are A. niger, A. versicolar, Trichophyton verrucosum Bodin and Saccharomyces cerevisiae, the ability of the four fungi isolate to be able to grow on the mineral salt medium with $1 \%$ of some petroleum compound showed they are all capable of using the petroleum fuel has their sole source of carbon and energy, Oyewole et al. (2021) also use similar approach to screen fungi isolate for diesel oil degrading potential. It was also reported that Aspergillus, Pencillium and Cephalosporium has the ability to degrade petroleum hydrocarbon. After being isolated from contaminated water, Candida lipolytica, Rhodotorula mucilaginosa, Saccharomyces cerevisiae, Geotrichum sp., and Trichosporon mucoides were discovered to degrade petroleum compounds (Das and Chandran 2010). This could be due to the presence of hydrocarbon degrading enzymes such as laccases, manganese peroxidases lignin peroxidases and lipase. Yusoff et al. (2020) reported that lipase is involved in inducing the lipolytic reactions of emulsified hydrocarbonat the lipid-water interface, thus assisting the hydrocarbon uptake and showed showed the presence of lipase intracellularly or extracellularly produced by hydrocarbon degraders Joutey et al. (2014) reported that fungi are effective, especially when it comes to breaking down natural polymeric materials, because they have extracellular multi-enzyme complexes. They can also colonize and penetrate substrates quickly, because of their hyphal networks, they can transfer and redistribute nutrients throughout their mycelium. Alkane-using yeasts include Candida lipolytica, Candida tropicalis, Rhodoturularubra, Aureobasidion, and Trichosporon pullulan. Diesel oil degradation was discovered in Rhodotorula aurantiaca and C. ernobii.

The result of the percentage of biodegradation of petroleum by bacterial isolate and colony forming unit increase with increase in incubation period. Corynebacterium xerosis had the maximal percentage of degradation on day 20 (86\%), Proteus vulgaris on day 25 with $80 \%$. and Bacillus 
subtilis maximal biodegradation percentage was on day 10 with $49.73 \%$. Trichophyton verrucosum Bodin on day 25 had the highest percentage (88\%) of biodegradation in comparison with the control $41 \%$ suggesting that other factor was responsible for the decrease in kerosene. While Aspergillus niger highest biodegradation was observed at day 15 having percentage degradation of $24 \%$. Corynebacterium xerosis increase from $4 \times 10^{6} \mathrm{cfu} \mathrm{g}^{-1}$ (day 0 ) to $270 \times 10^{6}$ $\mathrm{cfu}^{-1}$ (day 25), Bacillus subitilis had the minimum count of $1.6 \times 10^{4}$ on day 5 and maximal of $3.2 \times 10^{4}$ on day 25 , Proteus vulgaris increase from $1 \times 10^{5} \mathrm{cfu} \mathrm{g}^{-1}$ (day 5) to $56 \times 10^{5} \mathrm{cfu} \mathrm{g}^{-1}$ (day 25), Aspergillus niger had $1.5 \times 10^{2}$ on day 0 and $6.6 \times 10^{2}$ on day 15 and Trichophyton verrucosum had $1 \times 10^{6} \mathrm{cfu} \mathrm{g}^{-1}$ on day 5 and $5 \times 10^{6} \mathrm{cfu} \mathrm{g}^{-1}$ on day 25 . This revealed the potential of Corynebacterium species to use diesel oil as a sole carbon source, Bacillus subtilis to utilize spent engine oil as carbon source and Proteus vulgaris to use kerosene has carbon source. This might be due to the ability to produce biosurfactant, efficient hydrocarbon assimilation by receptor site for binding hydrocarbon and might have feature that enhance the emulsification and transport of hydrocarbon into the cell and the presence of enzymes such as oxygenase and peroxidase that introduce molecular oxygen into the hydrocarbon and produce intermediate that will later enter common energy yielding catabolic pathway (Abioye et al. 2013).

Aspergillus fungi utilize spent engine oil better than other fungi. This is in agreement with GeorgeOkafor et al. (2014) who reported that A. niger and A. versicolar degrade 98 percent of selected polycyclic aromatic hydrocarbons in liquid culture medium.

The percentage of degradation of the hydrocarbon increase with increase in incubation period with the highest on day $25(88 \%)$, the highest rate of biodegradation was seen by bacteria suggesting that bacteria has higher potential for biodegradation than fungi which might be due to the rapid growth of bacterial or short generation time compared to fungi in similar to Ali (2018) who reported from his study that bacteria were more active than fungi in the hydrocarbon biodegradation. The count monitored during the experiment is indicative of a steady increase in the number of fungal spores and a subsequent drop in the treatments, by the end of the incubation period. The eventual drop may be due to the number of spores which could be as a result of depletion of the only source of carbon in the medium, which is the Spent Engine Oil (Odili et al. 2020). 
The study shows that the Trichophyton verrucosum Bodin has the ability unlike other fungus to degrade kerosene fuel, however this species has not been cited as oil degrader by other authors. Aboiye et al. (2013) however reported that the rate of the biodegradation of oil by Saccharomyces cerivisiae also increase with increase in incubation period from 5 days to 25 days, this shows that the isolate can utilize the hydrocarbon as their source of carbon.

\section{CONCLUSION}

This study was able to isolate bacteria and fungi with biodegrading potential from petroleum products' contaminated soils. The isolates were identified as Corynebacterium sp, Proteus vulgaris, Bacillus subtilis, Aspergillus niger, A. versicolar, Trichophyton verrucosum Bodin and Saccharomyces cerevisiae. This study shows that it is possible to isolate bacteria and fungi capable of degrading complex hydrocarbon compound from contaminated soil and can be exploited for large scale clean-up of petroleum contaminated soil.

Ethical Approval: Not applicable

Consent to Participate: All the experiments were carried out in vitro by the researchers as undergraduate project work, under my supervision.

Consent to Publish: All the authors approved of the publication of this manuscript in ESPR

Authors Contributions: Oluwafemi A Oyewole: Supervised the research. Clement S Olusanya: Wrote the manuscript. Olusegun I Akinlade: carried out the research on biodegradation of spent engine oil using bacteria isolated from soil contaminated with spent engine oil. Yusuf O Abdulwasiu: carried out the research on the biodegradation of spent engine oil using fungi isolated from contaminated spent engine oil contaminated site. Anthony $\mathrm{O}$ Kelechi: carried out the research on the biodegradation of kerosene using fungi isolated from kerosene contaminated soil and Michael E Okoro carried out the research on the biodegradation of kerosene using indigenous bacterial isolates

Funding: No funding was received for this research

Competing Interests: No competing interest in the course of writing up this manuscript Availability of data and materials: Data and Materials are available for this research 


\section{REFERENCES}

Abioye PO, Akinsola OR, Aransiola AS, Damisa D and Auta HS 2013 Biodegradation of crude oil by Saccharomyces cerivisiae isolated from fermented zobo, Locally fermented beverage in Nigeria. Pakistan Journal of Biological Sciences. 16(24): 2058-2061. https://doi.org/10.3923/pjbs

Ahmed FM and Fakhruddin A 2018 A Review on environmental contamination of petroleum hydrocarbons and its biodegradation. International Journal of Environmental Scinence and Natural Resources. 11(3): 63-69. https//doi.org/10.19080/IJESNR

Ali AAW 2018 Biodegradation and phytotoxicity of crude oil hydrocarbons in an agricultural soil. Chilean Journal of Agricultural Research. 79(2): 266-277.

Ajiboye TO, Kuvarega AT and Onwudiwe DC 2020 Recent strategies for environmental remediation of organochlorine pesticides. Applied Sciences, 10(8): 6286. https://doi.org/10.3390/app10186286.

Bachmann LC, Lindau NT, Felder P and Schwab ME 2014 Sprouting of brainstem-spinal tracts in response to unilateral motor cortex stroke in mice. Journal Necrosci. 34(9): 3378-3389. https//doi.org/10.1523/JNEUROSCI.4384-13

Barnett HL and Hunter BB 1998 Illustrated genera of imperfecti fungi, $4^{\text {th }}$ Edition, APS press, St.Paul. 218

Chaudhary KD, Bajagain R, Jeong W and Kim J 2020 Biodegradation of diesel oil and n-alkanes (C18, C20, and C22) by a novel strain Acinetobacter sp. K-6 in unsaturated soil. Environmental Engineering Research. 25(3): 290-298. htpps://doi.org/ 10.4491/eer.2019.119

Cheesbrough M 2010. District laboratory practice in tropical countries. $2^{\text {nd }}$ Edition, Cambridge University Press, Cambridge, United Kingdom.

Das N and Chandran P 2011 Microbial degradation of petroleum hydrocarbon contaminants: an overview. Biotechnology Research International. 1-13. https://doi.org/ $10.4061 / 2011 / 941810$

Dadrasnia A and Agamuthu P 2011 Dynamics of diesel fuel degradation in contaminated soil using organic wastes. International journal of Environmental Science and Technology. https://doi.org/10.1007/s13762-013-0224-1

Ekanem JO and Ogunjobi AA 2017 Hdrocarbon degradation potentials of bacteria isolated from spent lubricating oil contaminated soil. Journal Applied Sciences Environment Management. 21(5): 973-979. https://doi.org/10.4314/jasem.v21i5.26.

Farber R, Rosenberg A, Rozenfeld S, Benet G and Cahan R 2019 Bioremediation of Artificial diesel-contaminated Soil Using bacterial consortium immobilized to plasma pretreated $\begin{array}{llll}\text { wood } & \text { waste. } & \text { Microorganisms. } & \text { 7(497: }\end{array}$ https://doi.org/10.3390/microorganisms7110497 
George-Okafor U, Taise F, and Muotoe-Okafor F 2009 Hydrocarbon degradation potentials of indigenous fungal isolates from petroleum contaminated soils. Journal of Natural and Physical Sciences, 3(1): 1-6.

Hasan FI 2014 Biodegradation of Kerosene by Aspergillus niger and Rhizopus stolinifer. Journal of Applied \& Environmental Microbiology. 2(1): 31-36. https://doi.org/10.12691/jaem

Joutey TN, Bahafid W, Sayel H and El-Ghachtouli N 2014 Biodegradation: Involved Microorganisms and Genetically Engineered Microorganisms. 290-320. http://dx.doi.org/10.5772/56194

Laurelta AT, Mudiaga I and Fovwe DO 2017 Bioremediation of diesel contaminated water using indigenous hydrocarbon degrading bacteria. International Journal of Scientific Research in Science and Technology. 3(1): 352-360

Lima SD, Olivera AF, Golin R, Lopes VCP, Caixeta DS, Lima ZM and Morais EB 2020 Isolation and characterization of hydrocarbon degrading bacteria from gas station leaking contaminated ground water in the Southern Amazon, Brazil. Brazilian Journal of Biology. 80(2): 354-361.

Mukred A, Hamid A, Hamza A and Yusoff W 2008 Growth enhancement of effective microorganism for bioremediation of crude oil contaminated water. Pakistan Journal of Biological Science. 11(13): 1708-1712.

Oyewole AO, Raji OR, Okeke KS, Musa OI, Chukwuma NG and Yakubu GJ 2021 Potential of fungi isolated from diesel contaminated soil to degrade diesel. Tanzania Journal of Science. 47(1): 47-56

Odilli UC, Ibrahim FB, Shaibu-imodagbe EM and Atta HI 2020 Comparative assessment of crude oil degradation by Monocillium sp. and Aspergillus niger. Journal of Applied Sciences and Environment, 24(5): 815-820

Rahman KS, Rahman T, Lakshmanaperumalsamy P and Banat IM 2002 Occurrence of crude oil degrading bacteria in gasoline and diesel station soils. Journal Basic Microbiol, 42(4): 28491. https://doi.org/10.1002/1521-4028

Shahida AA, Sadiya S, Shehu A, and Salau LA 2015 Biodegradation of spent engine oil by bacteria isolated from oil contaminated soil in mechanic workshop of Sokoto metropolis, Nigeria. Asian Journal of Science and Technology. 6(1): 993-999.

Tsuneo W 2010 Identification of Fungi: Pictorial Atlas of soil and seed fungi, morphologies of cultured fungi and key to species CRC Press

Yusoff DF, Rahman ARZ, Masomian M, Mohamad-Ali MS and Leow TC 2020 Newly isolated alkane hydroxylase and lipase producing geobacillus and anoxybacillus species involved in crude oil degradation. Catalyst Journal. 10(851): 1-15. 